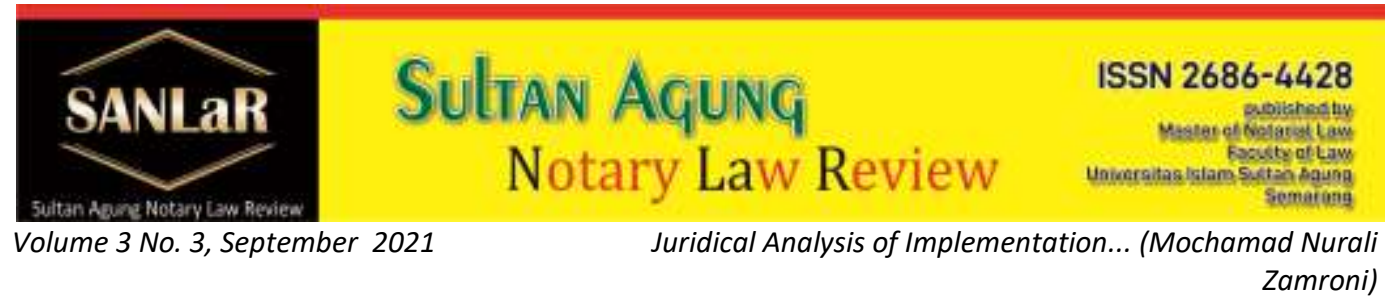

\title{
Juridical Analysis of Implementation of Rights Transfer to Land \& Buildings with Sale and Purchase Deed
}

\author{
Mochamad Nurali Zamroni*) \\ *) Faculty of Law, Universitas Islam Sultan Agung (UNISSULA) Semarang, E-mail: \\ mnuraliz2021@gmail.com
}

Abstract. The purpose of this research is to analyze and find out: 1). Implementation of the transfer of rights to land and buildings with a deed of sale and purchase at the Land Office of Grobogan Regency. 2). Obstacles and solutions in the implementation of the transfer of rights to land and buildings with a deed of sale and purchase at the Land Office of Grobogan Regency. The approach method in this research is normative juridical. The data used are primary and secondary data obtained through interviews and literature study, data analysis was carried out by analytical descriptive. The results of the research concluded: 1) The implementation of the transfer of rights to land and buildings with a deed of sale and purchase at the Land Office of Grobogan Regency, which starts with a sale and purchase transaction, after the sale and purchase is achieved, it must be AJB by PPAT and witnessed by the parties. PPAT must check the completeness of data such as certificates, proof of tax payments and complete identity of the parties. Furthermore, the PPAT Deed along with other files such as a registration application letter, land certificate or letter $D$, girik or other proof of ownership, identity of the parties, NPWP, marriage certificate and proof of payment of PBB tax payments are brought to the Land Office to be registered as a certificate of ownership for new land rights holders. After the registration process, the next step is to wait for data verification from the Land Office for the issuance of certificates. 2) Obstacles in the implementation of the transfer of rights to land and buildings with a deed of sale and purchase at the Land Office of Grobogan Regency, namely there are still many low levels of education, people are reluctant to take care of the transfer of land rights due to the costs which they think are quite high and will only take time. The length of the SOP (Standard Operational Procedure) for the Transfer of Name Certificate process, the lack of counseling given to the community regarding the importance of registering the transfer of land rights due to buying and selling, and land certificates. Solutions that can be done are to provide socialization or publish brochures, improve the performance of the Land Office through courses/training and improve administration because it is an organization of human resources.

Keywords: Transfer; Land; Rights; Sale; Purchase. 


\section{Introduction}

Today, the human need for land is increasing. TLand is a very basic human need. Humans live and carry out activities on the ground so that at any time humans are always in contact with the ground. ${ }^{1}$ The increasing demand for land along with the current limited availability of land also has a major impact on increasing the value and price of land. This increases the potential for land-related or landrelated conflicts and problems to arise. The increasingly complex problems of human life caused by land today require that there be a rule that regulates the guarantee of legal certainty in the relationship between humans and land. ${ }^{2}$

Through the right of control from the State, the State as the governing body will always be able to control or direct the management of the functions of the earth, water and space as well as the natural resources contained therein in accordance with existing regulations and policies, namely within the scope of juridical control with a public aspect. ${ }^{3}$ The forms of transfer of control of land rights can occur through legal acts of transfer of land rights. These legal actions include buying and selling, inheritance, grants, waqf, exchange auctions and so on. This transfer of rights causes the transfer of the right to control from one person to another.

One of the legal actions in transferring control of land and or building rights that is most often carried out by the community is through buying and selling. The seller is obliged to deliver the goods sold, while the buyer is obliged to pay the price of the goods purchased to the seller. ${ }^{4}$

Article 19 of Act No. 5 of 1960 stipulates that the sale and purchase of land must be proven by a deed made before the Land Deed Making Official (PPAT). So the sale and purchase of rights to land and or buildings must be carried out before the PPAT. This is as evidence that there has been a sale and purchase of land rights and then the PPAT makes a deed of sale and purchase. ${ }^{5}$ PPAT Deed is a deed made by PPAT as evidence that certain legal actions have been carried out regarding land rights or property rights to Flat Units. ${ }^{6}$ The deed proves that a legal act of transferring rights has been carried out in perpetuity and payment of the price. Because the legal action taken is a legal act of transferring rights, the

\footnotetext{
${ }^{1}$ Bambang Eko Supriyadi, 2013, Hukum Agraria Kehutana, Raja Grafindo, Jakarta, p. 7

${ }^{2}$ Dyara Radhite Oryza Fea, 2018, Panduan Mengurus Tanah Rumah dan Perizinannya, Legality, Yogyakarta, p. 2

${ }^{3}$ Muhammad Bakri, 2007, Hak Menguasai Tanah Oleh Negara (Paradigma Baru Untuk Reformasi Agraria), Citra Media, Yogyakarta, p. 5

${ }^{4}$ Soedharyo Soimin, 2004, Status Hak dan Pembebasan Tanah, ed. 1, Sinar Grafika, Jakarta, p. 94 5 Ibid, p. 95

${ }^{6}$ Article 1 paragraph (4) Government Regulation Number 24 of 2016 concerning Amendments to Government Regulation Number 37 of 1998 concerning Officials Making Land Deeds.
} 
deed proves that the recipient of the right (buyer) has become the new right holder. $^{7}$

The stages of making AJB have been regulated in the Regulation of the Head of the National Land Agency Number 8 of 2016 concerning Land Registration. Several conditions are required before AJB, among others, the seller's tax in the form of final income tax (PPh), as well as the buyer's tax in the form of Land and Building Rights Acquisition Fees (BPHTB). The final PPh amount is $2.5 \%$ of the acquisition of rights, while the amount of BPHTB is $5 \%$ of the value of the acquisition of rights after deducting the Acquisition Value of the Taxable Action Tax Object (NPOPTKP). The NPOPTKP value for each region is different, and is determined by the Regional Regulation of each region. After the deed is made, no later than 7 working days after the deed is signed, PPAT submits the deed to the Land Office for registration of the transfer of rights. ${ }^{8}$

Grobogan Regency, is one of the regencies in Central Java Province. Grobogan Regency is an area that is currently starting to progress due to a lot of development. ${ }^{9} \mathrm{~A}$ lot of development creates a lot of need for land. Most of the land and/or buildings owned by the community are land owned by sale and purchase.

\section{Research Methods}

The approach method used in this study is a normative juridical approach. Primary and secondary data sourcesobtained by interview method and literature review (study document). The data that has been collected both from field research and library research were analyzed using descriptive analysis methods.

\section{Results and Discussion}

3.1. Implementation of the Transfer of Rights to Land and Buildings with the Deed of Sale and Purchase at the Land Office of Grobogan Regency

Grobogan Regency is one of the regencies in Central Java province. The center of government or the district capital is in Purwodadi. In the 2020 Indonesian Population Census, the population of Grobogan district was $1,453,526$ people, with a population density of 719 people/km2. Grobogan Regency consists of 19 sub-districts, 7 sub-districts, and 273 villages.

\footnotetext{
${ }^{7}$ Adrian Sutedi, 2018, Peralihan Hak Atas Tanah dan pendaftarannya, ed.9, Sinar Grafika, Jakarta, p. 77

${ }^{8}$ lbid, p. 79

${ }^{9}$ https://www.grobogan.go.id/, accessed on December 26, 2020, at 21.00 WIB
} 
Grobogan Regency is the second largest district in Central Java after Cilacap Regency, and is directly adjacent to 9 other districts. The astronomical location of the area is between $110^{\circ} 15^{\prime}$ East Longitude $-111^{\circ} 25^{\prime}$ East Longitude and $7^{\circ}$ South Latitude $-7^{\circ} 30^{\prime}$ South Latitude, with a span from north to south of $\pm 37 \mathrm{~km}$ and from west to east $\pm 83 \mathrm{~km} .{ }^{10}$

In Grobogan Regency, the community can make a Deed of Sale and Purchase before the PPAT. The process of making a deed of sale and purchase of land rights must be attended by the seller and the buyer who carried out the legal act in question or his proxies and witnessed by at least 2 witnesses who meet the requirements to act as witnesses in the legal act. The land deed issued by the Land Deed Making Officer is made in 2 pieces, all of which are original. One sheet is kept at the PPAT office, while the other sheet is submitted to the Head of the Land Office for the purpose of registering the transfer of rights. Meanwhile, the parties concerned are given a copy.

The completeness of the documents that must be fulfilled by the parties in order to the making of the Sale and Purchase Deed (AJB), namely:

1. For land that has been registered, that is, it is proven by the existence of land certificate in the name of the rightful owner.

2. For unregistered land, namely land rights originating from conversion of old rights is proven by written evidence of the existence of rights such, in the form of letter $D$, tax or girik instructions, witness statements and the statement in question.

3. Certificate not in dispute

4. Identity of the parties.

5. The last UN.

PPAT is obliged to check the certificates of the parties applying for the deed of sale and purchase (AJB) to the local Land Office. In addition to examining Land Rights Certificates to the Land Office / BPN, PPAT will then examine the Deposit Receipts (STTS) and PBB Tax Returns.

After the deed is completed, the buyer must carry out the process of transferring the rights to the land he bought at the Land Office. Here's the processor the stages in the implementation of the Transfer of Rights to Land and Buildings with the Deed of Sale and Purchase at the Land Office of Grobogan Regency:

1. Meet the completeness of the required documents

${ }^{10}$ www.grobongankab.bps.go.id, accessed on 15 June 2021. 
a. A letter of application for registration of the transfer of rights signed by the recipient of the rights (buyer) or his proxies,

b. Land certificate in the name of the rightful owner.

c. Sale and Purchase Deed (AJB) that has been made together with the Seller in front of the PPAT.

d. Written power of attorney if represented

e. Proof of identity of the transferor (the seller)

f. Proof of identity of the party receiving the rights (buyer)

g. NPWP

h. Marriage certificate

i. Proof of payment of PBB tax payment, namely tax on acquisition of land and building rights (BPHTB) and income tax (PPh). If the land has no problems, in accordance with PP No. 34/2016, the PPAT office will ask the land buyer to pay an income tax of $2.5 \%$ of the gross value (the sale value of the land). Meanwhile, for the cost of checking and issuing $A J B$, the notary office sets different rates. That is why, buyers and sellers of land can first agree with each other to choose the PPAT office to be used. Until the issuance of AJB, usually the PPAT office will ask for a fee of around $0.5 \%$ to $1 \%$ of the total transaction value. Generally, these costs are included with notary services, transfer of names, and the making of a Sale and Purchase Deed. The whole process takes 30 days. $A J B$ that has been made 2 originals and 1 copy. For the cost of Land and Building Rights Acquisition Fee (BPHTB) of $5 \%$ of the price of the house and land minus the Acquired Value of Non-Taxable Tax Objects. This fee is only paid when submitting the application for the transfer of title to the land certificate at the BPN office. Sometimes tax collection is considered burdensome to the community. People feel it is unfair if they have to pay too much tax. Because there are many assumptions that develop that often many authorities misuse these tax funds.

This can be seen where the obligation to pay taxes and tax assessments imposed on the community has not been balanced with the ease in the process of obtaining refunds for overpayment of taxes and the completion of the audit process. The spirit of tax reform is to minimize meetings between tax officials and taxpayers. It is hoped that tax payments can run faster and safer so as to avoid fake SPTs and can reduce the occurrence of collusion between taxpayers and the tax authorities. This will not work, without good morals and ethics from both parties. ${ }^{11}$

At the time of signing the deed of sale and purchase, the blank deed of sale and purchase must first be filled in with the name of the PPAT along with witnesses from the PPAT whose working area covers the area where the

\footnotetext{
${ }^{11}$ Amin Purnawan, Rekonstruksi Sistem Pemungutan Pajak Penghasilan (PPh) Badan Berbasis Nilai Keadilan, Jurnal Dinamika Hukum Vol. 11 February 2011 Special Issue, p.42
} 
object of the land rights is located, and the names of the parties, the object of the sale and purchase are based on documents and data that have been submitted by the parties.

The uncertified land can be sold/transferred ownership rights with the main condition that the seller is able to show proof of land ownership such as previous sales and purchase letters (seal letters), Kekitir/petok/girik, information from the village head/local official, which explains the truth regarding ownership of the land owner. However, it should be underlined that in order to guarantee legal certainty over the transfer of land rights from the seller to the buyer, the transfer process must be carried out before the PPAT which later became the forerunner to the issuance of a certificate of ownership by the National Land Agency.

2. The Process of Implementing the Transfer of Rights Registration

The registration of the transfer of land rights by way of buying and selling at the Grobogan Regency Land Office can be carried out by the applicant directly or can be represented by his legal representative or can be represented by the PPAT. This is because in addition to PPAT's duty to make a deed of sale and purchase of land, PPAT is also in charge of registering the transfer of rights at the local land office which is no later than 7 days from the signing of the deed of sale and purchase of land rights. Before making the transfer of ownership rights to land by way of buying and selling, the PPAT concerned is obliged to re-examine the authenticity of the certificate to the Land Office. The cost that must be paid at the BPN Office is the cost of checking the validity of the original land certificate of Rp. 50,000. Another fee that must be paid at the BPN Office is the service fee for certificate transfer. The amount is the selling value of the land divided by 1,000 (land value (per square meter) $x$ land area (square meter) / 1,000). As an illustration, if the buyer of a land area of 1,000 square meters with a price per meter of Rp. 500,000, the fee for the transfer of the name of the land certificate at the BPN Office is Rp. 500,000 .

The registration process for the transfer of land rights by way of buying and selling at the Land Office of Grobogan Regency, namely:

1) The applicant brings the required documents to counter II.

2) The officer checks the completeness of the documents

3) Measurement when needed

4) The clerk estimates the registration fee

5) Applicant makes payment

6) Implementing Officer Make notes on the transfer of land rights in the land book and certificate 
7) Head of PPH and PPAT Sub-Section Correcting and validating documents (if true, it is returned to the PPH and PPAT implementing officers)

8) The Head of the Office corrects and validates the document (if true, it is returned to the PPH and PPAT implementing officers), initializes the notes on the transfer of rights in the land book and certificate, and forwards the documents to the implementing officer.

9) The implementing officer puts a stamp on the land book and certificate

10) Archive Officer - Warkah records the return of the land book, archives documents

11) Counter IV clerk makes proof of product delivery (D1 301 A), gives the number and date on D1 $301 \mathrm{~A}$ and submits a certificate to the applicant

3.2. Resistance and Solutions in the Implementation of the Transfer of Land and Building Rights with the Deed of Sale and Purchase at the Land Office of Grobogan Regency

Property rights are very important for humans to live their life in the world. The more the higher the value of property rights to an object, the higher also the award given to objects the. Land is one of the most valuable possessions valuable to mankind, as well as to Indonesia The Nature of Property Rights on Land. ${ }^{12}$

The transfer of ownership rights to land by way of buying and selling means the transfer of a land right from one party to another. In contrast to the transfer of a right, the transfer of a right indicates the existence of a deliberate legal act carried out by one party with the intention of transferring his property rights to another person. Thus, the transfer of property rights is known or desired by the party making the agreement on the transfer of land rights. The implementation of the registration of the transfer of ownership rights to land by way of buying and selling is regulated in the Basic Agrarian Act No. 5 of 1960, the implementation of which is regulated in Government Regulation Number 24 of 1997 concerning land registration.

There are several inhibiting factors, including:

1. Barriers from society

\footnotetext{
${ }^{12}$ Achmad Sulchan, Tinjauan Yuridis Tentang Perolehan Hak Atas Tanah Bagi Perempuan WNI Yang Terikat Perkawinan Campuran (Studi Kasus Putusan MK Nomor. 69/PUU XIII/2015), Jurnal Akta Vol. 4. No. 1, March 2017: 25 - 28, Unissula Semarang, p. 26
} 
a. There are still many low levels of education resulting in a lack of legal awareness.

b. Communities feel reluctant to take care of the transfer of land rights due to the costs which they think are quite high and will only take up their time.

c. The duration of the SOP (Standard Operating Procedure) for the process of transferring the name of a certificate whose proof of ownership is still in the form of a Sub-district Register C (Letter C). For example, in the case of buying and selling land, it turns out that the land does not yet have a Land Title Certificate, and the proof of ownership is still in the form of a Register C from the Kelurahan (Letter C).

a. Lack of counseling given to the community regarding the importance of registering the transfer of land rights due to buying and selling, and land certificates.

b. Lack of document storage space, so many documents are not organized and sometimes there are lost documents

The steps of the Grobogan Regency Land Office in overcoming obstacles to the process of transferring land rights through buying and selling are:

a. Provide or publish brochures about the importance of registering the transfer of land rights due to buying and selling. This step is done by giving the brochures to the community and sticking the brochures on the bulletin board at the Village Head's Office.

b. The Land Office collaborates with the Village Head to conduct counseling on land issues as an effort to raise public awareness about the importance of certificates.

c. By fixing the performance of the Land Office of Grobogan Regency, fixing the apparatus from within, namely the officers who handle the problem of registration of transfers and certificates of land rights, through courses/training.

d. The Grobogan Regency Land Office is trying to fix the administration because it is an organization of human resources.

\section{Closing}

Based on the description above, the conclusions in this study are: A) The implementation of the transfer of rights to land and buildings with a deed of sale and purchase at the Land Office of Grobogan Regency, which begins with a sale and purchase transaction between the seller and the buyer. After that the sale and purchase transaction must be made a deed of sale and purchase by the PPAT. PPAT will check PBB payments. At the same time to 
calculate the costs and taxes that are the obligations of each party. Furthermore, the PPAT Deed along with other files such as application letter for registration, land certificate or letter $D$, girik or other proof of ownership, identity of the parties, NPWP, marriage certificate and proof of payment of PBB tax payments are brought to the Land Office to be registered as a certificate of ownership. for new land rights holders. B) Obstacles and solutions in the implementation of the transfer of rights to land and buildings with a deed of sale and purchase at the Land Office of Grobogan Regency, namely 1). Barriers that arise from the community: a). There are still many low levels of education, resulting in a lack of legal awareness of the community, b). Communities feel reluctant to take care of the transfer of land rights due to the costs which they think are quite high and take up their time. 2). Barriers arising from the Land Office: a). Length of SOP (Standard Operational Procedure) Process for Transferring Names of Certificates whose Proof of Ownership is Still in the form of a Registered Letter C (Letter C) Kelurahan, b). Lack of counseling given to the community regarding the importance of registering the transfer of land rights due to buying and selling, and land certificates. c). Lack of storage space for documents, so that many documents are not organized and sometimes there are lost documents. The solution that can be done is to provide or publish brochures about the importance of registering the transfer of land rights due to buying and selling, holding counseling on land issues as an effort to raise public awareness about the importance of certificates.

\section{References}

Journals:

[1] A Chuasanga, Ong Argo Victoria. (2019). Legal Principles Under Criminal Law in Indonesia Dan Thailand, Jurnal Daulat Hukum, Vol 2, No 1 (2019) http://jurnal.unissula.ac.id/index.php/RH/article/view/4218

[2] Achmad Sulchan, Tinjauan Yuridis Tentang Perolehan Hak Atas Tanah Bagi Perempuan WNI Yang Terikat Perkawinan Campuran (Studi Kasus Putusan MK Nomor. 69/PUU XIII/2015), Jurnal Akta Vol. 4. No. 1, Maret 2017: 25 28, Unissula Semarang

[3] Alam, Bahrul., \& Khisni, Akhmad. (2020). Legal Protection of Holders of Land Loss Data In The City Land Office of Kendari. JURNAL AKTA: Vol.7, No. 2, 159-164. Retrieved from http://jurnal.unissula.ac.id/index.php/akta/article/view/7963

[4] Amin Purnawan, Rekonstruksi Sistem Pemungutan Pajak Penghasilan (PPh) Badan Berbasis Nilai Keadilan, Jurnal Dinamika Hukum Vol. 11 Edisi Khusus Februari 2011 
[5] Arrohim, Mohammad B., \& Wahyuningsih, Sri Endah. (2020). Analysis of Judicial Application of Criminal Penalty Against Notary / Land Deed Officials Conducting Making Crime of the Fake Authentic Deed in State Court of Semarang. JURNAL AKTA: Vol.7, No. 2, 183-188. Retrieved from http://jurnal.unissula.ac.id/index.php/akta/article/view/7891

[6] Deen, Thaufiq., Ong Argo Victoria \& Sumain. (2018). Public Notary Services In Malaysia. JURNAL AKTA: Vol. 5, No. 4, 1017-1026. Retrieved from http://jurnal.unissula.ac.id/index.php/akta/article/view/4135

Books:

[1] Abdul Aziz Muhammad Azzam, 2010, Figh Muamalat, terj. Nadirsyah Hawari, Amzah, Jakarta

[2] Abdurrahman As-sa"di, dkk., 2008, Fiqh Jual Beli: Panduan Praktis Bisnis Syari'ah, terj. Abdullah, Senayan Publishing, Jakarta

[3] Adrian Sutedi, 2018, Peralihan Hak Atas Tanah dan pendaftarannya, cet.9, Sinar Grafika, Jakarta

[4] Ali Achmad Chomzah, 2004, Hukum Agraria (Pertanahan Indonesia), Jilid 2, Prestasi Pustaka Publisher, Jakarta

[5] Amiruddin, 2012, Pengantar Metode Penelitian Hukum, Rajagrafindo Persada, Jakarta

[6] Bambang Eko Supriyadi, 2013, Hukum Agraria Kehutana, Raja Grafindo, Jakarta

[7] Dyara Radhite Oryza Fea, 2018, Panduan Mengurus Tanah Rumah dan Perizinannya, Legality, Yogyakarta

[8] Herlien Budiono, B, 2011, Ajaran Umum Hukum Perjanjian dan Penerapannya di Bidang Kenotariatan, Penerbit PT. Citra Aditya Bakti, Bandung

[9] Mokhammad Najih dan Soimin, 2012, Pengantar Hukum Indonesia, Setara Press, Malang

[10] Muhammad Bakri, 2007, Hak Menguasai Tanah Oleh Negara (Paradigma Baru Untuk Reformasi Agraria), Citra Media, Yogyakarta

[11] Muhammad Bakri, 2007, Hak Menguasai Tanah Oleh Negara (Paradigma Baru Untuk Reformasi Agraria), Citra Media, Yogyakarta

[12] Salim Hs, 2016, Teknik Pembuatan Akta Satu, Raja Grafindo Persada, Jakarta

[13] Soedharyo Soimin, 2004, Status Hak dan Pembebasan Tanah, cet. 1, Sinar Grafika, Jakarta

Regulation: 
[1] Act No. 5 of 1960 concerning Basic Regulations on Agrarian Principles

[2] Government Regulation Number 20 of 2015 concerning Land Agency

[3] Government Regulation Number 24 of 2016 concerning Amendments to Government Regulation Number 37 of 1998 concerning Officials Making Land Deeds.

[4] Presidential Regulation of the Republic of Indonesia Number 17 of 2015 concerning the Ministry of Agrarian Affairs and Spatial Planning 